\title{
Urban Flood Resilience in New York City, London, Randstad, Tokyo, Shanghai, and Taipei
}

\author{
$\mathrm{Yu}-\mathrm{Shou} \mathrm{Su}^{1 \& 2}$ \\ ${ }^{1}$ Inspector, National Development Council, Taiwan (R.O.C.) \\ ${ }^{2}$ Fellow, Penn Institute for Urban Research (Penn IUR), University of Pennsylvania, United States \\ Correspondence: Yu-Shou Su, National Development Council, 3F., No. 3 Baoqing Road, Taipei City 10020, \\ Taiwan (R.O.C.). Tel: 886-2-2316-5816. E-mail: yushou.su@gmail.com
}

\author{
Received: December 27, 2015 Accepted: January 8, 2016 Online Published: February 25, 2016 \\ doi:10.5539/jms.v6n1p92 URL: http://dx.doi.org/10.5539/jms.v6n1p92
}

\begin{abstract}
Making cities resilient to natural disasters has become a priority for many policy makers. However, few studies of global cities analyze environmental vulnerability, disaster resilience, or urban flood resilience. This article analyzes global cities' disaster resilience to flooding: New York City, London, Randstad, Tokyo, Shanghai, and Taipei. Case studies of those global cities will assist cities world-wide to prepare for the future. Results indicate that a hurricane could leave approximately $25 \%$ of New York City with severe economic losses by 2050 . In London, $15 \%$ of the land is located in flood-prone areas. The Thames Barrier began to operate to protect London from flooding in 1982. However, this also encouraged housing development closer to the river, and resulted in higher exposure and vulnerability of flooding. Randstad has approximately $40 \%$ of its land areas in flood-prone areas, but Randstad is well prepared for flood risk reduction by land-use and environmental planning. In Tokyo, extensive urbanization suffers from severe damages once flooding occurs. In Shanghai, approximately $50 \%$ of its land is in flood-prone areas. Shanghai is the most vulnerable to floods of the coastal cities. Shanghai is still not well prepared in land-use and environment planning for urban flood resilience. In Taipei, flood-prone areas account for approximately $41 \%$ of its total land area in an extreme weather scenario. Among these six global cities, Asian cities should focus more on urban flood resilience since most of flooding hotspots by 2025 will be located in Asian nations with having weak policies and actions, inadequate risk information, insufficient budgets and poor implementation capacities (UNISDR 2013). This research suggests that global cities, particularly Asian cities, should promote policies of urban flood resilience, focusing on land-use and environmental planning for resilience as well as strengthening their organizations and funding to reduce disaster risk, maintain up-to-date risk and vulnerability assessment. Urban policies should include environmentally responsible development in the face of continued population and economic growth, and being resilient regarding natural disasters. Cities can also adopt a growth management policy to direct development away from flooding hotspots. Urban regeneration policy should require developers to improve storm sewers, water retention ponds, and permeable surfaces. Planning more space for rivers, more constructed wetlands, and more ecological ponds to accommodate water is important. Cities can promote an actuarially fair flood insurance program which can reflect actual flood risks. A bottom-up community resilience plan would assist achieving urban resilience.
\end{abstract}

Keywords: urban resilience, flood prevention, urban sustainability, global city flood resilience

\section{Introduction}

The United Nations' estimation of losses from disasters around the world is between $\$ 250$ billion to $\$ 300$ billion each year (Wahlström, 2015). Since the 1980s, the number of climate-related disasters around the world has increased dramatically, often devastating cities. The number of floods around the world has soared since the 1980 s, few studies analyzing the environmental vulnerability and flood resilience of major cities in developed countries. On the contrary, in developing countries, approximately $30-50 \%$ of urban populations live in environmentally fragile areas (United Nations Department of Economic and Social Affairs, 2013). The World Bank also describes the growth in developing countries as sensitive to natural disasters. Much of the vulnerability facing Asian nations stems from the region's rapid urbanization. Their cities are among the most vulnerable to natural disasters, and remain the least prepared to deal with them. Further, the United Nations International Strategy for Disaster Reduction (UNISDR, 2013) describes Asia as having weak policies and 
actions, inadequate risk information, insufficient budgets and poor implementation capacities. The rapid urbanization in Asian nations along with little preparedness for natural disasters are likely to dramatically increase the damage from natural disasters in the future. This article first builds on the current urban food resilience discourse through literature reviews. Second, it studies in the six global cities: New York City, London, Randstad, Tokyo, Shanghai, and Taipei. Case studies of urban flood resilience will assist cities world-wide to prepare for the future. Third, this article analyzes strategies to prevent cities from flooding and suggests urban flood resilience policies to address the vulnerabilities of cities.

\section{Literature Reviews of Resilience and Urban Flood Resilience}

Resilience is gaining influence. Resilience originally meant the ability of a system to return to its original condition after a disturbance. Stemming from the Latin word "resilire", the original meaning of resilience was the ability of a substance or object to spring back. Equilibrium resilience focused on the ability of a system to return to its normal condition after a disturbance (Holling, 1973). However, the resilience debate is shifting from equilibrium resilience to adaptive, evolutionary, and social-ecological resilience. This results in shifting the very meaning of "resilience" from "bouncing back" to "bouncing forward" in the twenty-first century (see Table 1). Resilience discourse and debate also influence the rebuilding policy from back to normalcy to retreating from potential natural disasters. In a city's practices, the urban resilience to flooding moves from the engineering strategy of blocking out floods to the land-use planning strategy of accommodating floods or retreating from flood risk. Rather than engineers, land-use or environmental planners will play a key role in urban resilience to flooding.

Table 1. Summary of the "bouncing back" vs. "bouncing forward" resilience debate

\begin{tabular}{lll}
\hline Aspect & Bouncing back & Bouncing forward \\
\hline Period & In the 1970s & In the 2000s \\
& Return to normalcy; bounce back quickly; & Adapt, evolve, change, and transform gradually \\
Core value & $\begin{array}{l}\text { recovery time matters; engineering resilience; } \\
\text { resistance }\end{array}$ & $\begin{array}{l}\text { into another condition; prepare for change; } \\
\text { adaptive resilience; retreat }\end{array}$ \\
The ability of a system to return to an & The ability of a system to adjust and adapt in the \\
Characteristic & equilibrium condition after disturbance & face of changing conditions \\
& Traditional, rigid, and conservative & Adjustable, adaptive, and flexible
\end{tabular}

In the field of urban planning, resilience is still a new topic. There is a lack of studies in urban resilience. Literature reviews indicate the lack of articles regarding urban resilience and resilience planning. Few books and articles have promoted resilience planning since 2000. For instance, Vale and Campanella (2005), The Resilient City, explain how modern cities recover from disasters, particularly after devastating earthquakes and city fires; Birch and Wachter (2006), Rebuilding Urban Places after Disaster, written after Hurricane Katrina, describes how to rebuild, prepare for disaster risk reduction, and make cities less vulnerable by different levels of government in partnership with the private sector and public will. Regarding journal articles, this study finds no article pertaining to urban resilience and resilience planning in the Journal of Planning Education and Research (JPER) in 1995-2014. The Journal of the American Planning Association (JAPA) from 1999 to 2009 has published only one article with urban resilience in the title: Campanella (2006) "Urban Resilience and the Recovery of New Orleans". This article argues that urban resilience involves much more than rebuilding. He describes "urban resilience is largely a function of resilient and resourceful citizens as well as a strong citizen involvement at the grassroots level" (Campanella, 2006).

However, there are other articles related to urban resilience, such as rebuilding, post-disaster planning, and natural hazard mitigation planning. There are 10 articles with a title related to these topics in the JPER during the past twenty years, mostly published after 2005. For instance, Berke et al. (2009) "Integrating Hazard Mitigation into New Urban and Conventional Developments"; Birch (2009) "Response to "Post-Disaster Planning in New Orleans: It Isn't as Simple as It Seems"; Mueller et al. (2011) "Looking for Home after Katrina: Postdisaster Housing Policy and Low-Income Survivors"; Berke et al. (2014) "Impacts of Federal and State Hazard Mitigation Policies on Local Land Use Policy"; Highfield et al. (2014) "Mitigation Planning: Why Hazard Exposure, Structural Vulnerability, and Social Vulnerability Matter". Hence, the research of urban resilience and resilience planning is still a new focus in the planning field starting in the 2000s.

In the Journal of the American Planning Association (JAPA), there are 6 articles with a title of natural disaster, rebuilding, resilience, or recovery. Before 2005, there are only 2 articles related to rebuilding: Olshansky (2001) 
"Land Use Planning for Seismic Safety: The Los Angeles County Experience, 1971-1994" and Nelson et al. (2002) "Plan Quality and Mitigating Damage from Natural Disasters: A Case Study of the Northridge Earthquake with Planning Policy Considerations". Both articles adopt a case study on earthquakes and mitigation planning. After devastating Hurricane Katrina in 2005, there are more articles discussing urban resilience. For example, there are 2 out of 9 articles in the JAPA's Spring 2006 discussing urban resilience: Campanella (2006) "Urban Resilience and the Recovery of New Orleans" and Olshansky (2006) "Longer View: Planning After Hurricane Katrina". Campanella argues that urban resilience involves much more than rebuilding. Learning from the experience of population replacement of urban renewal since the 1960s, he puts more emphasis on people than on buildings. He stresses that urban resilience is largely a function of resilience and resourceful citizens as well as citizen involvement. Olshansky argues that post-disaster recovery is all about urban planning. The application of planning knowledge and process in data, communication, participation along with funding and coordination among the different levels of government will lead to urban resilience.

In addition to the JAPA and the JPER, a new journal focused on resilience was released in 2010, the International Journal of Disaster Resilience in the Built Environment (IJDRBE). There are more articles discussing urban resilience. In particular, the IJDRBE's Issue 1 of 2013: "Special Issue: Making Cities Resilient". Many articles discuss rebuilding experiences and disaster risk reduction, mainly developing countries' case studies. The IJDRBE has been an important journal for promoting urban resilience research since 2010.

\section{Practices and Policies of Urban Flood Resilience in Global Cities}

Global cities in developed and developing countries can't be immune from flooding. As Kunreuther and Michel-Kerjan (2009) indicate, the $21^{\text {st }}$ century has been termed as "at war with the weather". Floods become more frequent and severely damaging because of rapid urbanization and extreme weather conditions. This article analyzes urban flood vulnerability and practices of flooding prevention in six global cities in both developed and developing countries, including New York City, London, Randstad, Tokyo, Shanghai, and Taipei.

\subsection{New York City's Flood Resilience Plan after Hurricane Sandy}

In New York City, devastating Hurricane Sandy in 2012 caused 43 deaths, \$19 billion in damage, destroyed 90,000 buildings in the inundated zone, left 2 million people without power, 11 million travelers affected daily, and 1.1 million children unable to attend school for at least a week. New York City projects that in 2050 the flooding areas of each neighborhood with an expected loss of $\$ 30$ million will be five times greater than the actual loss they experienced in 2012 from Hurricane Sandy (see Figure 1). By the 2050s, the number of neighborhoods facing severe economic losses will account for approximately $25 \%$ of all neighborhoods in New York City (The City of New York 2013). The Regional Plan Association projects an estimated 2.2 million people in the New York-New Jersey-Connecticut region will be at high risk of flooding from sea level rise and storm surge by 2050 . Critical facilities will face inundation in the next few decades, including $59 \%$ of the region's power generating capacity, $21 \%$ of public housing and four out of the region's six airports (Regional Plan Association 2015). Therefore, the cooperation of the federal, state, and local governments aimed to achieve resilience.

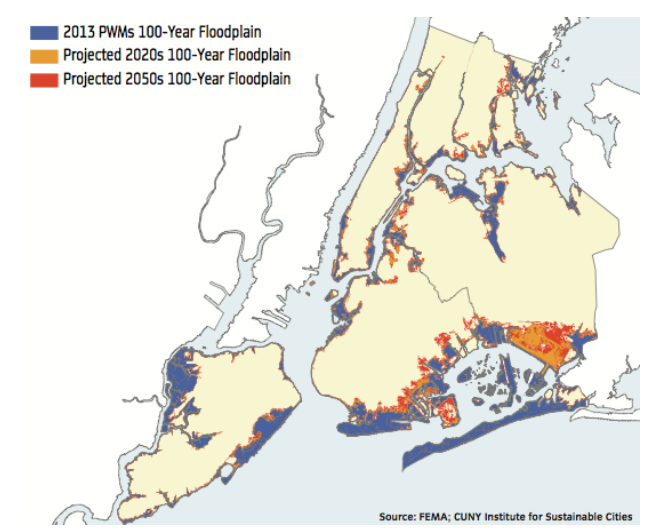

Figure 1. Future flood simulation for New York City by 2020 and 2050

Source: The City of New York 2013. 
The U.S.A. Federal Government report Hurricane Sandy Rebuilding Strategy (2013) was to establish guidelines for the investment of $\$ 50$ billion in Federal funds, made available for recovery and set the region on the path to being built back more resilient and stronger. The New York State Government report Recommendations to Improve the Strength and Resilience of the Empire State's Infrastructure (2013) concentrated on regional coastal resilience. Resilience strategies integrate restoration and enhancement of natural systems, hard structures, and land use controls to achieve multiple benefits. Another report NYS 2100 Commission recommended the inclusion of natural mitigation methods as well as traditional engineering solutions. Finding and implementing natural and green methods for protection creates a crucial complement both to existing and new structural defenses. A broader adoption of green infrastructure can minimize local problems with flooding.

Further, New York City Government report Climate Risk Information 2013: Observations, Climate Change Projections, and Maps (2013) provides new climate change projections and future coastal flood risk maps for New York City. This climate risk information is designed to assist with community rebuilding plans, and help to increase resilience of communities. There are two important parts: climate projections and future coastal flood risk maps. This report also gives average climate change projections for the year 2050. The temperature projection for New York City is an increase of $4.0^{\circ} \mathrm{F}$ to $5.5^{\circ} \mathrm{F}$. The precipitation projection is an increase of $5 \%$ to $10 \%$. A sea level rise of 11 to 24 inches is projected. Huber and Gulledge (2011) indicate that "what used to be a 500 -year flood event may become a 100-year or 10-year event, so that most people will experience such events within their lifetimes". Aerts et al. (2009) predict that "sea level rise alone in New York City may cause the current 1 in 100 year flood to occur approximately four times more often than by the end of the century. Moreover, by then, the current 1 in 500 year flood event may occur approximately once every 200 years" (Aerts et al. 2009). Federal Emergency Management Agency (FEMA) and New York City are updating their flood risk maps within the 100- and 500-year flood zones. These up-of-date flood risk maps should help to make people aware of their flood risks and thus have better risk communication and resilience planning strategies.

The purpose of another New York City report A Stronger, More Resilient New York (2013) is to: 1. analyze the impact of Hurricane Sandy on the city's buildings, infrastructure, and people; 2. assess the risks the city faces from climate change in the 2020s and 2050s; 3 . outline ambitious and comprehensive, yet achievable strategies for increasing resilience citywide. This report examines the economic losses: $\$ 19$ billion in 2012; $\$ 35$ billion by the 2020s; and $\$ 90$ billion by the 2050s. By the 2050s, with rising sea levels and more intense storms, a once-in-70-year loss event would cause an estimated $\$ 90$ billion of damage, or almost five times the asset damage and economic loss caused by Hurricane Sandy in 2012. Furthermore, the expected annual losses in New York City of $\$ 1.7$ billion today will grow to $\$ 4.4$ billion in current dollars by the 2050s (The City of New York 2013). Expected losses will be concentrated in more areas of the city than were impacted during Hurricane Sandy. The total flooding areas with the neighborhood experiencing losses of $\$ 30$ million account for $5 \%$ of its land in New York City in 2012. New York City also projects that in 2050 the total flooding areas and damages will be five times greater than actual loss they experienced in 2012 from Hurricane Sandy. By the 2050s a hurricane could leave approximately $25 \%$ of New York City with severe economic losses.

In order to address flood damage, New York City Government had to develop a resilient plan for citywide hard and soft infrastructure, coastal protection, insurance, utilities, transportation, parks, water, and revise building codes. Besides, the City Government also developed five community rebuilding and resilience plans: the Brooklyn-Queens Waterfront; the East and South Shores of Staten Island; South Queens; Southern Brooklyn; Southern Manhattan. Although New York City has a good resilience plan, how to pay for rebuilding will be an issue. The resilience plan consists of 250 initiatives which will cost nearly $\$ 20$ billion, including a ten-year plan of Special Initiative for Rebuilding and Resiliency of $\$ 14$ billion. There is a funding gap estimated to be approximately $\$ 4.5$ billion. However, from New York City's experience, it is clear what strategies are important in resilience planning: 1. engaging in climate change projection and disaster assessment; 2 . examining fiscal losses and cost-benefit analysis; 3 . developing space scenario planning; 4. developing community rebuilding and resiliency plans; 5 . identifying and funding key initiatives.

Additionally, the Regional Plan Association's Fourth Regional Plan is undertaking to address the New York-New Jersey-Connecticut region's natural disasters and to strengthen regional resilience. According to the Regional Plan Association (2015), the Fourth Regional Plan will take a comprehensive and long term look at the role of resilience in the region's development. There are five broad categories of spatial resilience strategies: resist, rebuild, restore, retain, and retreat (see Figure 2). The fifth "R", retreat, must inevitably be singled out from the other four. Retreat is not an engineered solution. Retreat is also often the last tool chosen from the resilience toolbox. However, there are many areas in the region where engineered strategies are expensive or cannot address the particular risks of communities. "Retreat strategies will have to be implemented in some 
places, and ignoring retreat as an option entirely will limit the opportunities to successfully implement a resilience plan" (Regional Plan Association 2015).

\begin{tabular}{|c|c|c|c|c|c|}
\hline Project/Policy/Proposal & $\begin{array}{l}\text { 믈 } \\
\text { 렬 }\end{array}$ & $\frac{\hbar \underline{n}}{\ddot{g}}$ & 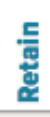 & 屯ั & $\frac{\pi}{8}$ \\
\hline Bay Barriers & & $\mathbf{x}$ & & & \\
\hline Coastal Barriers, Hard & & $\mathbf{x}$ & & & \\
\hline Coastal Barriers, Soft & $\mathbf{x}$ & $\mathbf{x}$ & & $\mathbf{x}$ & \\
\hline Buyout Programs & & & & & $\mathrm{x}$ \\
\hline Rolling Easements & & & & $\mathbf{x}$ & $\mathrm{x}$ \\
\hline Building Retrofit, Zoning & $\mathbf{x}$ & & & & \\
\hline "Resist, Delay, Store, Discharge" & & $\mathbf{x}$ & $\mathbf{x}$ & $\mathbf{x}$ & \\
\hline Wetlands Restoration & & & & $\mathbf{x}$ & \\
\hline Green Infrastructure & $\mathbf{x}$ & & $\mathbf{x}$ & & \\
\hline Living Shorelines & & & $\mathbf{x}$ & $\mathbf{x}$ & \\
\hline
\end{tabular}

Figure 2. Resilience strategies of the 5Rs: rebuild, resist, retain, restore, and retreat for New York-New Jersey-Connecticut region

Source: Regional Plan Association, 2015.

\subsection{London's Flooding Vulnerability and Risk Reduction Practice}

London's population has grown rapidly, from 6.8 million in 1986 to 8.4 million in 2013, and is predicted to 9 million by 2020 and 10 million by 2035 . Housing strategy aims to build at least 42,000 homes a year (Greater London Authority, 2014). However, London's housing development should include environmentally responsible development in the face of increased storms and floods. In general, there are three main flood risks facing London: tidal surges, river water, and surface water. The largest concentrations of risk are around rivers, especially the Thames River, where flooding is often the result of heavy rainfall (Greater London Authority, 2002). Notable was the flooding of autumn, 2000, inundating England and Wales, where the Association of British insurers estimated that the cost to insurers was approximately $\$ 2$ billion (or $£ 1.3$ billion). The flood levels in many places were the highest on record. Approximately 10,000 properties were flooded at over 700 locations and there was widespread disruption to road and rail services (UK's Environment Agency, 2001). London's rapid growth, floodplain development, land-use modifications, the increase of impermeable surfaces, and an intensification of rainfall led to an increasing flood risk. The population grew from 6.8 million in 1986 to 8.4 million as of 2014 in Greater London (UK National Statistics), which gave it higher exposure to floods. More and more people and properties are vulnerable to flooding, leading to increased damages. The value of property at risk is approximately $\$ 120$ billion (or $£ 80$ billion), resulting from the Thames tidal floodplain with a probability of $0.1 \%$ annual risk of flooding (Great London Authority 2002). Fifteen percent of London is located in flood risk areas where flooding is probable (see Figure 3).
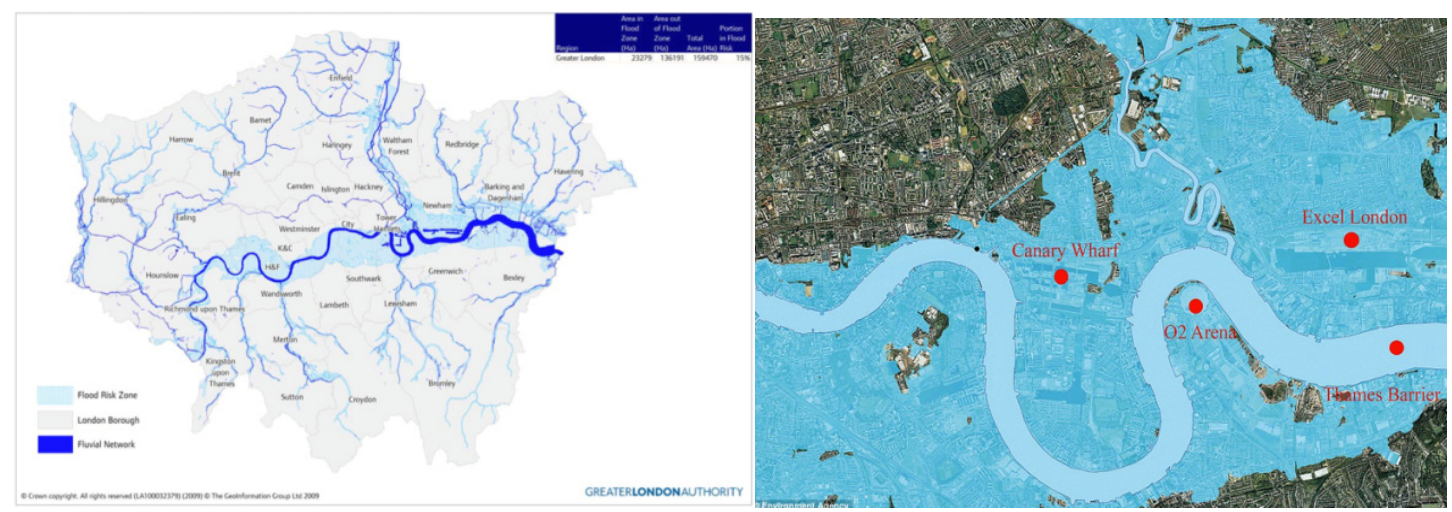

Figure 3. Approximately $15 \%$ of London is located in flood-prone areas

Source: Great London Authority 2009; 2012. 
The Greater London Authority (2012) also notes that up to 680,000 properties, approximately $19 \%$ of housing is at risk of surface water flooding in a rainstorm with an annual probability of $0.5 \%$. There is a $20 \%$ probability of a home being flooded in a 40 years span. There are 24,000 properties which are at significant risk of river flooding (London Assembly Environment Committee 2014). When analyzing the different locations of housing built in different periods, the result indicates that the newer housing was built in the more flood-prone areas around the Thames River, particularly after the 1980s. This has resulted in a higher vulnerability in London.

The Thames Barrier, the world's largest movable flood barriers, began to operate to protect London from flooding in 1982. However, this encourages housing development closer to the river because people assumed the Barrier could stop flooding. However, Wiering and Immink (2006) indicate the flooding control facilities creates a "flood control paradox" or "flood vicious cycle", strengthening dikes or barriers encouraged more intensive land use. When a flood event does happen, more damage occurs. Then, barriers or dikes will be strengthened again, which results in more developments. Thus, a large amount of housing developments in London after the 1980s are located in the flood-prone areas. In addition to the Thames Barrier, London's policy to prevent flooding in the future primarily focuses on increasing the capacity of drainage systems and of river restoration. London will create more space for flood waters to be held in the upstream river catchment and soak back into the ground. London Assembly Environment Committee (2014) indicates that allowing low-lying areas to flood safely at times of high water flow should protect homes, roads and businesses. Hence, engineering structures and barriers, improvement of the drainage system, and river restoration are major strategies to reduce flood risk in London.

\subsection{Randstad and the Netherlands's Experience of Urban Flood Resilience}

With about half the population at flooding risk, the Netherlands built a complex system of dams, dikes, and movable floodwalls. The Netherlands has been managing flood risks since the twentieth century. There are approximately 9 million people residing below sea level; some areas lie at 7 meters below mean sea level, making them the lowest areas in Europe (Aerts et al., 2009). OECD (2014) indicates that the Netherlands is a country where $55 \%$ of the territory is below sea level or flood prone. Approximately $65 \%$ of the Netherlands' GDP is produced below sea level. Over the last 100 years, more than 10,000 hectares of land have been elevated to several meters above sea level using fill materials. However, flooding has threatened the Netherlands throughout history (Aerts et al., 2009). Effective protection of this low-lying land is important. Many low-lying parts have been reclaimed from former lakes, referred to as polders, and are protected by 53 levee rings along the main rivers and coastal areas (Aerts et al., 2009). Hence, the construction, reconstruction, and the strength of these levee rings has become the most important strategy for flooding resilience in the Netherlands. Kolen et al. (2010) note that the Netherlands has focused primarily on flood prevention, resulting in a flood defense system with the highest safety standards in the world. For example, the protection system, levees and barriers, around the Randstad and the economic heart of the Netherlands is designed to resist a storm that is estimated to occur once in every 10,000 years (a possibility of $0.01 \%$ annually). This is the highest standard of structural defenses in the world. However, even the highest standard of flood control structures can not guarantee "zero flooding". In the history of floods in the Netherlands, the 1953 flood was the most severe, and caused 400,000 hectares to flood, 40,000 buildings were damaged, more than 1,800 people killed, and 70,000 people had to be evacuated. Woltjer and $\mathrm{Al}$ (2007) note that after the flooding from the violent North Sea storm in 1953 killed nearly 2,000 people, the Netherlands undertook a vast engineering program called Deltawerken, the Delta Plan, which included building a system of dams, barriers, and higher dikes. The Delta Plan was formulated in 1954 and was complete in 1997. During the four decades, massive structures were built to prevent flooding. An example would be the construction of large closure dams across the mouths of the four main coastal inlets southwest of the Netherlands. Also, increasing the strength and raising the height of the dikes and dunes along the rest of the coast and along the coastal inlets was completed. The four types of flood safety standards, being applied to the coast, estuaries, rivers and the transitional zones under the Dutch national law, the 1996 Flood Defense Act, are based on one flood once in 1,250 years, 2,000 years, 4,000 years, and 10,000 years. The highest level of resistance to flooding is the protection system constructed in the 1990s. For the river region, the standards are based on an exceeding frequency of one flood in 1,250 years. For the transitional zones between the rivers and the coast, the standard is on an exceeding frequency of one in 2,000 or 4,000 years. The coastal area is once in every 10,000 years.

The Netherlands' traditional technical approach towards water management aims to ensure safety and protect land by blocking out water. Aerts et al. (2009) indicate that the Dutch flood protection system consists of 10,550 miles of levees (1,800 miles designated as primary levees and 8,750 miles as secondary levees), 300 structures such as sluices and bridges, shortening coastline to reduce the length of the levees exposed to the sea by 
approximately 400 to 450 miles. The Dutch flood protection system is one of the most extensive engineering undertakings in the world. However, despite the highest level of protection, absolute safety cannot be guaranteed Climate change, economic growth, the increase in the population and new insights into the probability of flooding and the probable consequences of dike failure are forcing the Dutch government to rethink their policies of blocking out water. After heavy floods in 1993 and 1995, the Dutch government began to realize that the traditional defense and dike were no longer sufficient. Wiering and Immink (2006) indicate that floods in 1993 and 1995 were due to excess local rainfall, and have accelerated the current developments of water management discourse between the existing "battle against water" discourse versus the new discourse of "accommodating water". However, a new approach to rebuild, retreat, or resilience to flooding is necessary after floods in the 1990s following the failure of the highest level of structural protection systems.

In 2001, the Dutch government initiated a project of Flood Risks and Safety in the Netherlands (Floris) to analyze and simulate flooding in the 16 out of 53 dike rings with conservative assumptions and a worst-case scenario. This means that flooding risks may possibly be overestimated and that the probability of flooding is greater relative to the situation than if the uncertainty had not been taken into account. The results show that more than $40 \%$ of land areas are in flood-prone areas with a depth from 0 to 6.5 meters (see Figure 4). The Dutch Cabinet outlined a radically different water management approach in 2000. Using a strategy referred to as "retain, store and drain", the policy makers break with the traditional approach which is to "pump and drain as fast as possible". This new approach will help to ensure that water problems are not simply passed on to lower-lying areas of the Netherlands. The Dutch government began to rely more on planning than on the engineering structures for urban resilience to flooding of the 21 st century. City and regional planning plays a key role in flood prevention. For example, this project spent approximately $\$ 2.5$ billion (or 2.3 billion euro) from 2007 to 2015 to lower and broaden floodplains, to create river diversions and temporary water storage areas, and to restore marshy riverine landscapes. The new planning method, Spatial Planning Key Decision: Room for the River, for urban resilience to flooding coordinates land-use, environmental planning, and water management to make cities resilient in the Netherlands. Dikes will only be improved where other measures are either inappropriate or unaffordable (The Minister of Transport, Public Works and Water Management 2007). Hence, Dutch flood prevention is shifted from rebuilding or dike reinforcement to river relief, retreat and resilience.

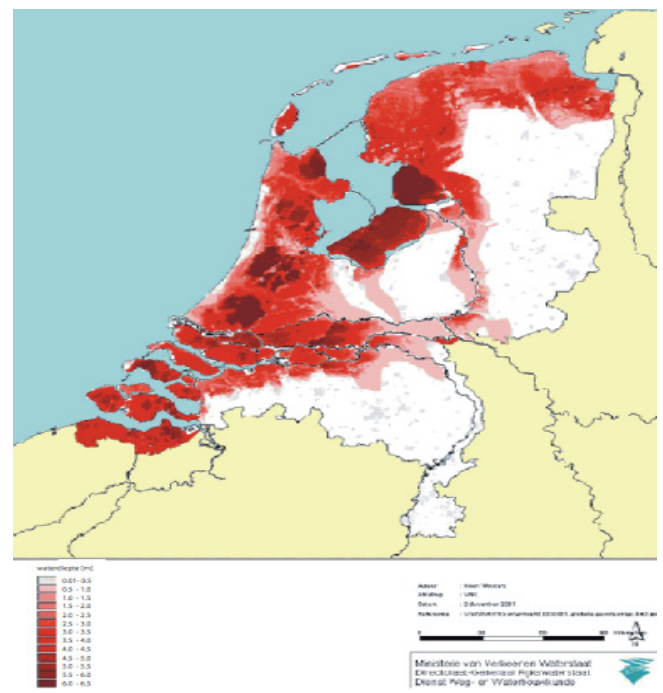

Figure 4. Flood-prone areas with a depth from 0 to 6.5 meters in the Netherlands, more than $40 \%$ of total land in hotspots

Source: The Minister of Transport, Public Works and Water Management (MTPWM) 2005.

\subsection{Tokyo's Flooding Vulnerability and Risk Reduction Practice}

Tokyo is the most populous urban agglomeration in Asia, with a population of over 37 million as of 2014. The Greater Tokyo Area is home to approximately $26 \%$ of Japan's total population (The World Bank, 2009). Extensive urbanization in Tokyo has reduced the water storage capacity of the land, causing rapid runoff into rivers during rainfall events. Due to its highly concentrated population and assets, Tokyo suffers from severe damages once flooding occurs. Furthermore, the eastern delta region has 1.5 million people living under the 
high-tide level, making it necessary to implement measures against storm surges. Tokyo's most severe flooding was caused in 1958 by the Kano River Typhoon. The 76 millimeters (or 3 inches) rainfall within an hour broke the record. The 1958 flooding caused more than 200 deaths and damaged half a million houses within the inundation areas of 82 square miles, approximately $10 \%$ of the total area of Tokyo (see Figure 5). This was the largest submerged area and largest proportion of land area in flooding from 1910 to 2014.

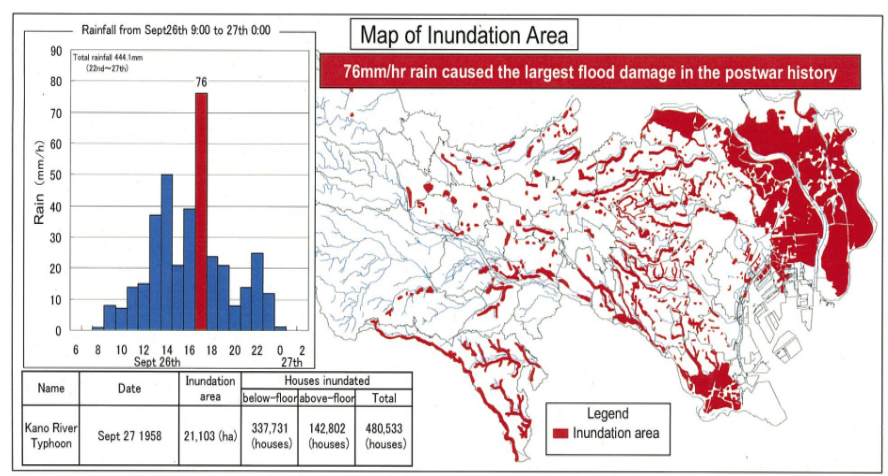

Figure 5. Tokyo's most severe flood, $10 \%$ of the total land was inundated in Tokyo

Source: Tokyo Metropolitan Government.

In order to reduce the $10 \%$ of Tokyo in a flood-prone area, the Tokyo Metropolitan Government is engaged in river improvement projects so as to enable the rivers to safely drain a flood of an hourly rainfall of 50 millimeters (or 2 inches) by expanding the river width or digging down into the riverbed. Additionally, numerable flood control programs were constructed after the 1980s. Notable are two projects: the Kanda River underground regulating reservoir (1988-2008) and the Tokyo Metropolitan Area Outer Underground Discharge Channel (1992-2009). The Kanda River underground regulating reservoir was completed in 2008 at a cost of approximately $\$ 0.8$ billion ( $\$ 100$ billion Japan Yen). This is the largest flood control reservoir in Tokyo with a 12.5 meter inner diameter and 4,500 meters in length with a storage capacity of 540,000 cubic meters. It utilizes the underground space to prevent flooding of the Kanda River, where many buildings stand adjacent to the river on both sides. The second major project in flood risk reduction, the Tokyo Metropolitan Area Outer Underground Discharge Channel, is the world's largest underground flood water diversion facility. This project aims to protect the city of Tokyo itself from floods during heavy rainfall and typhoons. It was completed in 2009 after 17 years of construction, at a cost of approximately $\$ 2$ billion. The facility is capable of withstanding a flood of once in every 200 years. The project includes five huge silos, a 6.3 kilometers connecting tunnel, a storage tank and 78 pumps. The five concrete containment silos are 65 meters deep and 32 meters in diameter. They are located within certain limits from the rivers. The five silos act as flow regulators. The silos are connected to a 10.6 meters diameter tunnel. The tunnel is constructed 50 meters underground, passing through the silos. The tunnel sends the water to the storage tank when the silos reach their capacity. The water storage tank is 25.4 meters high and 177 meters long. It is supported by 59 pillars which are 20 meters tall and weigh 500 tons.

\subsection{Shanghai's Flooding Vulnerability and Risk Reduction Practice}

China's economic development has made Shanghai, its largest city by population with 23 million people, a global financial center. However, Shanghai is located in low-lying areas at an average of thirteen feet above sea level, and at the mouth of the Yangtze River. The Huangpu River flows through the heart of Shanghai. Because of Shanghai's topology, land subsidence problem, and sea level rise threat, Shanghai is more vulnerable to flooding. Shanghai's recent floods were mainly caused by typhoons. For example, Typhoon Winnie of 1997 brought the highest recorded water level, 5.72 meters higher than the normal water level. This typhoon caused the deaths of 3,500 people and economic losses of $\$ 3.2$ billion in total. Another typhoon, Typhoon Haikui of 2012, affected approximately 3.2 million residents, inundated up to 2,900 houses, and suspended the operation of 30,000 businesses. Typhoon Haikui eventually forced Shanghai to raise its highest-level alert and prepare for flooding ( $\mathrm{Li}, 2005)$.

Shanghai has the highest vulnerability to floods among coastal cities (see Figure 6). Balica et al. (2011) analyze nine large coastal cities' flood vulnerability index (from 0 to 1 , the higher, the more vulnerable), based on exposure, susceptibility and resilience to coastal flooding. Results show that Shanghai has the highest flood vulnerability index, meaning that Shanghai is the most vulnerable city in comparison with these coastal cities: 
Buenos Aires, Calcutta, Casablanca, Dhaka, Manila, Marseille, Osaka, and Rotterdam. Regarding Shanghai, Balica et al. find that "the prosperous Chinese metropolis was more vulnerable than poorer cities such as Dhaka". Additionally, they indicate that Rotterdam and Osaka were the least vulnerable to floods, and the poorest cities, most exposed socially and with weak institutional organizations, have a very low resilience to floods (Balica et al. 2011).

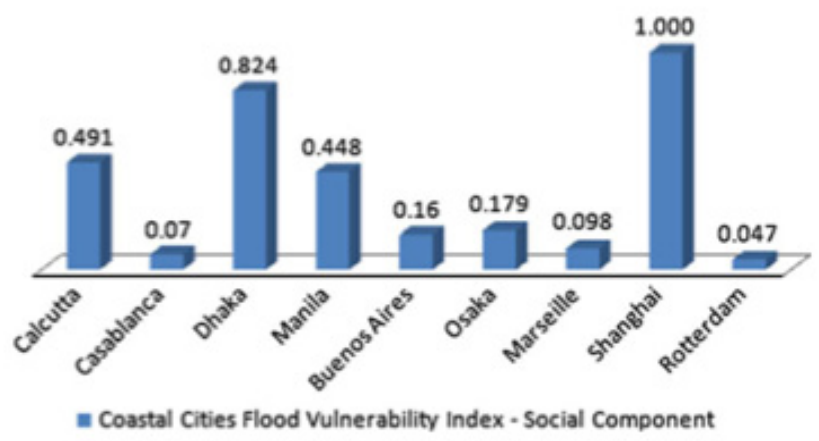

Figure 6. Shanghai, the highest flood vulnerability index among coastal cities

Source: Balica et al. 2011.

However, Cai (2012) notes that Shanghai officials express skepticism about the result. Shanghai's flood control authority indicates that "the city is capable of resisting typhoons and floods, rejecting claims that it is the most vulnerable city" (Shanghai Municipal Government, 2012). Shanghai Flood Control Headquarter explains that 523 kilometers of coastal levees have been built according to the city's flood control standard, designed to withstand a once-in-200-year flood. Additionally, the evacuation plan is the priority, the city's ability to quickly evacuate people in coastal areas during extreme weather conditions. For instance, when Typhoon Haikui of 2012 came, Shanghai evacuated 374,000 people from their makeshift houses in coastal areas, or construction new sites within one and a half days (Shanghai Municipal Government, 2012). Since the 2010s, Shanghai has developed its flood risk map by using the geographical information system (GIS) to map the flood-prone areas with different scenarios, once in 250-year, 500-year, and 1000-year floods. The map indicates that approximately $50 \%$ of Shanghai would be in flood-prone areas, the highest flooding depth would be 6.7 meters. The Yin et al. (2013) study also indicates that in the absence of adaptation measures, storm flooding will cause up to $40 \%$ more inundation, particularly upstream of Huangpu River. Thus, Shanghai could possibly have the largest proportion of any city located in flood-prone areas among the other mentioned global cities.

\subsection{Taipei's Flooding Vulnerability and Risk Reduction Practice}

Global cities in developed and developing countries can't be immune from flooding. As Kunreuther and Michel-Kerjan (2009) indicate, the $21^{\text {st }}$ century has been termed as "at war with the weather". Floods become more frequent and severely damaging because of rapid urbanization and extreme weather conditions. This article analyzes urban flood vulnerability and practices of flooding prevention in six global cities in developed and developing countries, including New York City, London, Randstad, Tokyo, Shanghai, and Taipei. Taipei City is the capital as well as the economic, political, and cultural center of Taiwan. Floods caused extensive damage during the 1960s while Taipei was experiencing fast urbanization. Flooding is a major threat to Taipei because Taipei is developed in a basin, a river mouth, and low-lying topography in a coastal zone. Flood inundation along riversides caused by the heavy precipitation that is associated with rainstorms and typhoons frequently occurs in lowlands and floodplains (Shih et al., 2014; Chen et al., 2006; Hsieh et al., 2006 ; Pan et al., 2012). The topographic characteristics of the Taipei Basin and the increasingly extreme weather events, such as more rainfall occurring over shorter periods and increasingly more intense precipitation, have resulted in more floods. Moreover, urbanization has led to increased flooding since the 1960s. For instance, Taipei's irrigation systems were converted into roads during the 1970s, which increased runoff and led to more floods. Additionally, highway and expressway construction through Taipei in the 1970s and 1980s removed some of the branches of the Keelung River. This resulted in less flood retention space and more stormwater runoff, which also caused more floods. Further, the lower reaches of the Keelung River were reshaped and replaced by a man-made river which was intended to reduce floods. Instead, the history of flooding in Taipei from 1991-2012 indicates that this area, known as Shezi Island of Taipei's Shilin District, was the most flood-prone area. After the reshaping of the river, more development along the man-made river resulted in an even higher potential for flood damages. 
Su's study (2015) indicates that Taipei's flood-prone areas account for approximately $41 \%$ of its total land area. Among Taipei's flood-prone areas, it is estimated that $10 \%$ would be flooded above 0.5 meter in an extreme weather scenario (see Figure 7). The vulnerable population is estimated at 200,000 people, or $7 \%$ of the total population. Eight percent of the total households, or 83,000 households, and $10 \%$ of the buildable land are vulnerable to flooding depths above 0.5 meter. The GDP impact will be more than $\$ 28$ billion, accounting for $8 \%$ of Taipei City's GDP. More than $\$ 67$ billion worth of property is vulnerable.
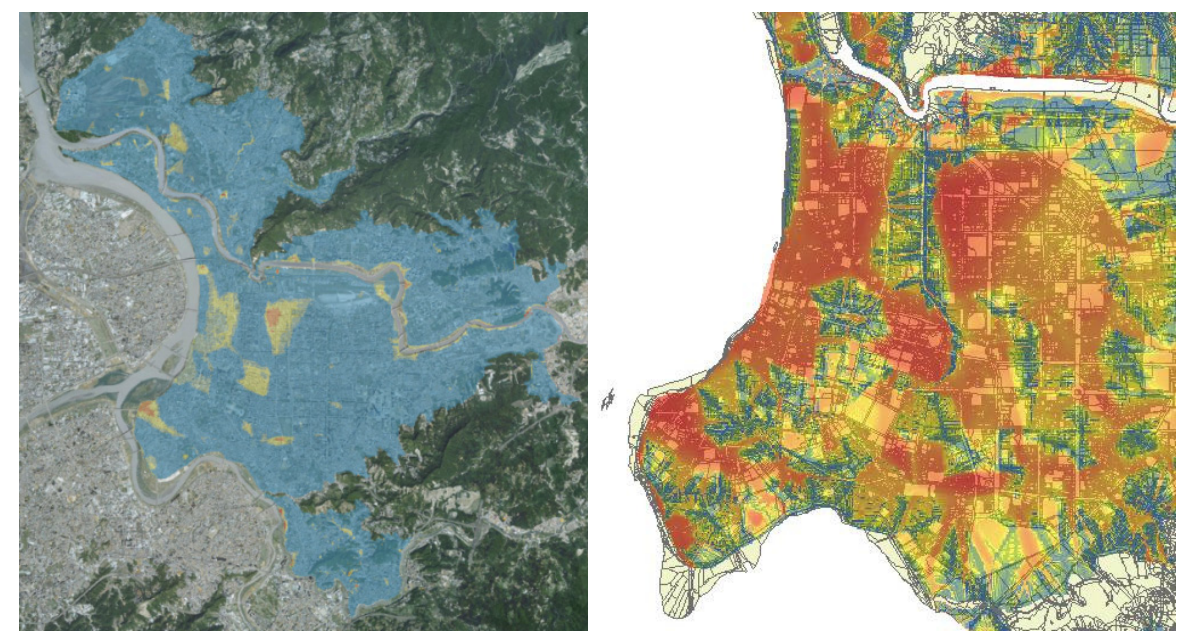

Figure 7. Taipei flood hotspots in downtown with areas in high density, land value, and critical facilities

Source: $\mathrm{Su} 2015$.

A chronology of steps were implemented to prevent floods in Taipei (see Figure 8). After the 1960s, Taiwan's central government and Taipei city government implemented flood control projects, including floodways, levees, flood diversion systems, flood control gates and pump stations, and storm sewer systems. In the early 1970s, Taiwan's central government planned a new town, the Linkou New Town, to move people from Taipei's area of high risk for flooding. However, the engineering strategy of using flood control facilities such as levees, dikes, flood control gates, and pumping stations created a "flood control paradox" (Wiering and Immink, 2006). Strengthening levees encouraged more intensive land use and development which resulted in higher damage when floods did occur. Flash floods, along with the failure of pumping stations along the Keelung River, caused by Typhoon Nari in 2001 flooded downtown Taipei. This study finds that coordination problems between different governmental agencies hampered the effectiveness of flood prevention policies. For instance, a river and its watershed management in Taipei is divided into at least three sections, and each section has three different central government agencies primarily in charge of river management, soil and forest conservation of watershed, and flood prevention policy. This has resulted in inefficiency and ineffectiveness. The improvement of storm sewer systems has reduced the flood risk since the late 1990s. However, some storm sewer systems were designed to use the principle of gravity, allowing the water to flow from higher to lower places. Downtown Taipei is the low-lying area of the Taipei Basin. Hence, the effectiveness of storm sewer systems in downtown is diminished because of the gravity design and Taipei's topology. Drainage depending on pumping stations at outlets of the storm sewer system has been implemented. Many pumping stations were built along the Keelung River and Tamsui River. In order to have a more comprehensive flood prevention policy, Taipei has changed the strategy of flood control and fortification since the 2000s. Taipei's Comprehensive Flood Control Project was initiated in 2003 to include conserving upstream water flow, minimizing mid-stream flooding, and controlling downstream flooding. 


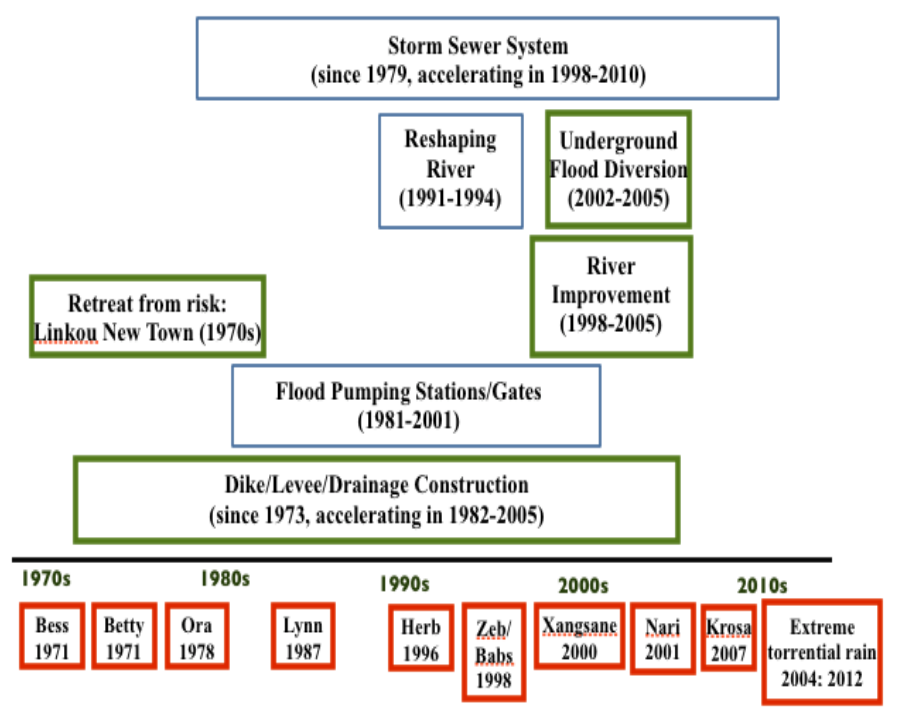

Figure 8. A chronology of policies implemented to protect Taipei from flooding

Source: Su 2015.

\section{Conclusions and Suggestions}

Urban resilience planning is still quite a new topic with lack of practice and implementation. In city planning, resilience was not an emphasis until the sustainable development movement and devastating natural disasters occurred in the twenty-first century. The concept of sustainability helps resilience planning, but sustainability and resilience are different. Sustainable development mainly focuses on equity and efficiency of resource use. However, resilience planning concentrates mostly on the adaptive strategies after disasters or preventive policies for disaster risk reduction. Adaptive resilience for "bouncing forward" has become a core value of resilience. The more adaptive, persistent, and transformable their system, the more resilient a city is. Although sustainability and resilience are different in meaning, scope, and practice, they have a relationship of integrative dependence. A resilient city must be a a sustainable city. Urban resilience planning increases the sustainability of a city.

Results indicate that a hurricane could leave approximately $25 \%$ of New York City with severe economic losses by 2050 . In London, $15 \%$ of the land is located in flood-prone areas. Randstad has approximately $40 \%$ of its land areas in flood-prone areas. Extensive urbanization in Tokyo suffers from severe damages once flooding occurs. Shanghai, up to $50 \%$ of its land in flood-prone areas, is the most vulnerable to floods of the coastal cities. In Taipei, flood-prone areas account for approximately $41 \%$ of its total land area in an extreme weather scenario. Making cities resilient to flooding has therefore become a priority for many policy makers because the number of floods around the world has soared dramatically since the 1980s. Major cities in both developed and developing countries can't be immune from flooding, especially in Asian cities with having weak policies and actions, inadequate risk information, insufficient budgets and poor implementation capacities. This has resulted in significant damages.

This research suggests that global cities, particularly Asian cities, should promote comprehensive policies of urban flood resilience, focusing on land-use and environmental planning for resilience as well as strengthening their organizations and funding to reduce disaster risk, maintain up-to-date risk and vulnerability assessment. Urban policies should include environmentally responsible development in the face of continued population and economic growth, and being resilient regarding natural disasters. Asian cities can also adopt a growth management policy to direct development away from flooding hotspots. Urban regeneration policy should require developers to improve storm sewers, water retention ponds, and permeable surfaces. Planning more space for rivers, more constructed wetlands, and more ecological ponds to accommodate water is important. Cities can also promote an actuarially fair flood insurance program which can reflect actual flood risks. A bottom-up community resilience plan would assist achieving urban flood resilience. In doing so, urban flood resilience can be achieved in global cities. 


\section{Acknowledgments}

This study is part of Yu-Shou Su's Ph.D. Dissertation in City and Regional Planning, University of Pennsylvania, United States. A special gratitude to Dr. Eugénie L. Birch for her professionalism, enthusiasm, and encouragement that have helped this research.

\section{References}

Aerts, J., Major, D. C., Bowman, M. J., Dircke, P., \& Marfai, M. A. (2009). Connecting Delta Cities. Amsterdam, Netherlands: VU University Press.

Balica, S. F., Wright, N. G., \& Meulen, F. van der. (2011). A flood vulnerability index for coastal cities and its use in assessing climate change impacts. Nat Hazards, 64, 73-105. http://dx.doi.org/10.1007/s11069-012-0234-1

Berke, P. R., Lyles, W., \& Smith, G. (2014). Impacts of Federal and State Hazard Mitigation Policies on Local Land Use Policy. Journal of Planning Education and Research, 34(1), 60-76. http://dx.doi.org/10.1177/0739456X13517004

Berke, P. R., Song, Y., \& Stevens, M. (2009). Integrating Hazard Mitigation into New Urban and Conventional Developments. Journal of Planning Education and Research, 28, 441-455. http://dx.doi.org/10.1177/0739456X09331550

Birch, E. L. (2010). Response to “Post-Disaster Planning in New Orleans” It Isn’t as Simple as It Seems.

Birch, E. L. (Ed.). (2009). The Urban and Regional Planning Reader. Routledge.

Birch, E. L., \& Wachter, S. M. (2011). World Urbanization: The Critical Issue of the Twenty-First Century. In E. L. Birch \& S. M. Wachter (Eds.), Global Urbanization. University of Pennsylvania Press. http://dx.doi.org/10.9783/9780812204476.3

Birch, E. L., \& Wachter, S. M. (Eds.). (2006). Rebuilding Urban Places after Disaster: Lessons from Hurricane Katrina. University of Pennsylvania Press.

Brammer, H. (2010). After the Bangladesh Flood Action Plan: Looking to the future. Environmental Hazards, 9 , 118-130. http://dx.doi.org/10.3763/ehaz.2010.SI01

Cai, A. (2012). Shanghai Vulnerable to Flooding from Future Climate Change? Berkeley Energy and Resources $\begin{array}{lll}\text { Collaborative } & \text { (BERC). } & \text { Retrieved }\end{array}$ http://berc.berkeley.edu/shanghai-vulnerable-to-flooding-from-future-climate-change/

Campanella, T. J. (2006). Urban Resilience and the Recovery of New Orleans. Journal of the American Planning Association, 72(2). http://dx.doi.org/10.1080/01944360608976734

Chang, L.-F., Seto, K. C., \& Huang, S.-L. (2013). Climate Change, Urban Flood Vulnerability and Responsibility in Taipei. In C. G. Boone \& M. Fragkias (Eds.), Linking Urban Ecology, Environmental Justice and Global Environmental Change: A Framework for Urban Sustainability. Springer Press. http://dx.doi.org/10.1007/978-94-007-5666-3_11

Chen, A. S., Hsu, M. H., Tsng, W. H., Huang, C. J., Yeh, S. H., \& Lien, W. Y. (2006). Establishing the database of inundation potential in Taiwan. Nat Hazards, 37, 107-132. http://dx.doi.org/10.1007/s11069-005-4659-7

Chen, B. (2005). Resist the Earthquake and Rescue Ourselves: The Reconstruction of Tangshan after the 1976 Earthquake. The Resilient City: How Modern Cities Recover from Disaster. Oxford University Press.

Chen, H. L., Chen, L. C., Haruo, H., \& Maki, N. (2007). Clarifying Flooding Vulnerable Space in Urban Areas: Formation of Urban Flooding in the Taipei Basin. The 2nd International Conference on Urban Disaster Reduction. Taipei, Taiwan.

Chen, L.-C., \& Chen, H.-L. (2007). Exploring Flooding Vulnerability during Urban Developing Process: Learning from the Formation of Taipei Basin Floods. Journal of City and Planning, 34(3), 293-315. (In Chinese)

City of New York. (2013). PlaNYC: A Stronger, More Resilient New York. City of New York.

Daniels, T., \& Steinberg, H. (2006). Lessons from Sri Lanka. In E. L. Birch \& S. M. Wachter (Eds.), Rebuilding Urban Places after Disaster: Lessons from Hurricane Katrina. University of Pennsylvania Press.

Davoudi, S. (2012). Resilience: A Bridging Concept or a Dead End? Planning Theory \& Practice, 13(2), 299-333. http://dx.doi.org/10.1080/14649357.2012.677124 
Davoudi, S. (2014). Climate change, securitization of nature, and resilient urbanism. Environment \& Planning C: Government \& Policy, 32(2), 360-375. http://dx.doi.org/10.1068/c12269

Department of Urban Development, Taipei City Government. (1991). Keelung River Control Project of Taipei City. Department of Urban Development, Taipei City Government. (In Chinese)

Goldstein, B. E. (2012). Collaborative Resilience: Moving Through Crisis to Opportunity. The MIT Press.

Greater London Authority. (2002). Flooding in London A London Assembly Scrutiny Report November 2002.

Greater London Authority. (2009). London Regional Flood Risk Appraisal: First Review.

Greater London Authority. (2009). London Regional Flood Risk Appraisal.

Greater London Authority. (2012). London Strategic Flood Framework. Retrieved from http://www.london.gov.uk/sites/default/files/archives/london-prepared-London-Strategic-Flood-FrameworkV2.pdf

Greater London Authority. (2014). Housing in London 2014: The evidence base for the Mayor's Housing Strategy. $\quad$ Retrieved from http://www.london.gov.uk/sites/default/files/Housing\%20in\%20London\%202014\%20-\%20Final_1.pdf

$\begin{array}{llll}\text { Greater } & \text { London } & \text { Authority. } & \text { (2014). }\end{array}$ https://www.london.gov.uk/media/assembly-press-releases/2014/04/revive-rivers-to-reduce-flood-risk-in-lo ndon

Greater London Authority. (2014). Homes for London: The London Housing Strategy 2014. Retrieved from http://www.london.gov.uk/sites/default/files/Draft\%20London\%20Housing\%20Strategy\%20April\%202014 - $0 . p d f$

Hein, C. (2005). Resilient Tokyo: Disaster and Transformation in the Japanese City. The Resilient City: How Modern Cities Recover from Disaster. Oxford University Press.

Highfield, W. E., Peacock, W. G., \& Zandt, S. V. (2014). Mitigation Planning: Why Hazard Exposure, Structural Vulnerability, and Social Vulnerability Matter. Journal of Planning Education and Research, 4(3), 287-300. http://dx.doi.org/10.1177/0739456X14531828

Hotelling, C. S. (1973). Resilience and Stability of Ecological System. Annual Review of Ecology and Systematics, 4, 1-23. http://dx.doi.org/10.1146/annurev.es.04.110173.000245

Hsieh, L. S., Hsu, M. H., \& Li, M. H. (2006). An assessment of structural measures for flood-prone lowlands with high population density along the Keelung River in Taiwan. Nat Hazards, 37, 133-152. http://dx.doi.org/10.1007/s11069-005-4660-1

Hsu, M. H., Chen, S. H., \& Chang, T. J. (2000). Inundation simulation for urban drainage basin with storm sewer system. Journal of Hydrology, 234, 21-37. http://dx.doi.org/10.1016/S0022-1694(00)00237-7

Hsu, M.-H, Chen, C.-H., Chang, C.-H., Liu, W.-C., Chang, T.-J., Lin, Y.-C., ... Butler, D. (2013). Flood Impact Assessment under Climate Change Scenarios in Central Taipei Area, Taiwan. International Conference on Flood Resilience. UK.

Hsu, W.-K., Huang, P.-C., Chang, C.-C., Chen, C.-W., Hung, D.-M., \& Chiang, W.-L. (2011). An integrated flood risk assessment model for property insurance industry in Taiwan. Nat Hazards, 58, 1295-1309. http://dx.doi.org/10.1007/s11069-011-9732-9

Huang, L.-L. (2008). Taipei: Post-Industrial Globalization. In G. W. Jones \& M. Douglass (Eds.), Mega-urban regions in Pacific Asia: urban dynamics in a global era. Singapore: NUS Press.

Huang, S.-L. (1989). Integrating storm-water management concept for the development of the Kuantu plain in the city of Taipei. Landscape and Urban Planning, 18(1), 37-53. http://dx.doi.org/10.1016/0169-2046(89)90054-6

Huber, D., \& Gulledge, J. (2011). Extreme Weather and Climate Change, Center for Climate and Energy Solutions (C2ES formerly the Pew Center on Global Climate Change). Retrieved from http://www.c2es.org/publications/extreme-weather-and-climate-change

ICLEI-Local Governments for Sustainability. (2002). ICLEI's Resilient Communities and Cities (RC\&C) initiative.

IPCC. (2007). Climate Change 2007: Synthesis Report. Contribution of Working Groups I, II and III to the 
Fourth Assessment Report. Retrieved from http://www.ipcc.ch/pdf/assessment-report/ar4/syr/ar4_syr.pdf IPCC. (2014). Summary for Policymakers. IPCC Working Group III Contribution to AR5.

Kolen, B., Holterman, S., Zuilekom, K. van, Friso, K., \& Helsloot, I. (2010). If things do go wrong- influence of road capacity on mass evacuation in the event of extreme flooding in The Netherlands. Retrieved from http://www.hkv.nl/site/hkv/upload/publication/

Kunreuther, H., \& Michel-Kerjan, E. O. (2009). At war with the weather: managing large-scale risks in a new era of catastrophes. Massachusetts Institute of Technology. http://dx.doi.org/10.7551/mitpress/9780262012829.001.0001

Kunreuther, H., \& Roth, R. (1998). Paying the Price: The Status and Role of Insurance Against Natural Disasters in the United States. Washington, DC: Joseph Henry Press.

Li, Y. (2015). Protection of Shanghai from Flooding—Open or closable navigational section? Master Thesis, Technical University of Delft, Delft, the Netherlands.

Liao, K.-H. (2012). A Theory on Urban Resilience to Floods-A Basis for Alternative Planning Practices. Ecology \& Society, 17. http://dx.doi.org/10.5751/ES-05231-170448

Lin, Y.-C., Hsu, M.-H, Chang, T.-J., Tsai, M.-Y., Liu, W.-C., Chen, A. S., ... Butler, D. (2012). Flood Vulnerability and Risk Maps in Taipei City, Taiwan. 2nd European Conference on FLOOD risk Management, 20-22 November 2012, Rotterdam, The Netherlands. http://dx.doi.org/10.1201/b13715-113

London Assembly Environment Committee. (2014). Flood Risks in London: Summary of Findings. Retrieved from https://www.london.gov.uk/sites/default/files/14-04-07-Flood\%20risk\%20slide\%20pack\%20-\%20FINAL.p df

McHarg, I. (1969). Design with Nature. The Natural History Press.

Mitchell, J. K. (1999). Crucibles of Hazard: Mega-cities and Disasters in Transition. United Nations University Press.

Mueller, E. J., Bell, H., Chang, B. B., \& Henneberger, J. (2001). Looking for Home after Katrina: Postdisaster Housing Policy and Low-Income Survivors. Journal of Planning Education and Research, September, 31.

Multihazard Mitigation Council. (2005). Natural Hazard Mitigation Saves: An Independent Study to Assess the Future Savings from Mitigation Activities. National Institute of Building Sciences, Washington, DC.

Munich RE. (2012). Review of natural catastrophes in 2011. Retrieved from http://www.munichre.com/site/corporate/get/documents_E1171980501/mr/assetpool.shared/Documents/0 Corporate\%20Website/6_Media\%20Relations/Press\%20Releases/2012/2012_01_04_press_release_en.pdf

Nelson, A. C., \& French, S. P. (2002). Plan Quality and Mitigating Damage from Natural Disasters: A Case Study of the Northridge Earthquake with Planning Policy Considerations. Journal of the American Planning Association, 68(2). http://dx.doi.org/10.1080/01944360208976265

New Geography. (2012), Evolving Urban Form: Dhaka. Retrieved from http://www.newgeography.com/content/003004-evolving-urban-form-dhaka

OECD. (2007). OECD Territorial Reviews: Randstad Holland, Netherlands.

OECD. (2014). OECD Reviews of Risk Management Policies: Seine Basin, Ile-de-France, 2014 Resilience to Major Floods.

OECD. (2014). Water Governance in the Netherlands: Fit for the Future? OECD Studies on Water. http://dx.doi.org/10.1787/9789264102637-en

OECD. Poverty and Climate Change Reducing the Vulnerability of the Poor through Adaptation. Retrieved from http://www.oecd.org/env/cc/2502872.pdf

Olshansky, R. B. (2001). Land Use Planning for Seismic Safety: The Los Angeles County Experience, 1971-1994. Journal of the American Planning Association, 67(2). http://dx.doi.org/10.1080/01944360108976227

Olshansky, R. B. (2006). Longer View: Planning After Hurricane Katrina. Journal of the American Planning Association, 72(2). http://dx.doi.org/10.1080/01944360608976735

Olshansky, R. B. (2009). Planning for natural hazards. Local planning: contemporary principles and practice. 
ICMA.

Olshansky, R. B., Johnson, L. A., Horne, J., \& Nee, B. (2008). Longer View: Planning for the Rebuilding of New Orleans. Journal of the American Planning Association, $74(3)$. http://dx.doi.org/10.1080/01944360802140835

Pan, T. Y., Chang, L. Y., Lai, J. S., Chang, H. K., Lee, C. S., \& Tan, Y. C. (2012). Coupling typhoon rainfall forecasting with overland-flow modeling for early warning of inundation. Nat Hazards, 70(3), 1763-1793. http://dx.doi.org/10.1007/s11069-011-0061-9

Peduzzi, P., Dao, H., Herold, C., \& Mouton, F. (2009). Assessing global exposure and vulnerability towards natural hazards: the Disaster Risk Index. Natural Hazards and Earth System Sciences, 9, 1149-1159. http://dx.doi.org/10.5194/nhess-9-1149-2009

Penning-Rowsell, E. C., \& Handmer, J. W. (1988). Flood Hazard Management in Britain-A Changing Scene. The Geographical Journal, 154(2), 209-220. http://dx.doi.org/10.2307/633847

Pickett, S. T. A., Cadenasso, M. L., \& Grove, J. M. (2004). Resilient cities: meaning, models, and metaphor for integrating the ecological, socio-economic, and planning realms. Landscape and Urban Planning, 69, 369-384. http://dx.doi.org/10.1016/j.landurbplan.2003.10.035

Regional Plan Association, America 2050. Retrieved from http://www.america2050.org/northeast.html

Regional Plan Association. (2015). Where to Reinforce, Where to Retreat? Fourth Regional Plan Roundtable. Retrieved from http://library.rpa.org/temp/files/4RP-Whitepaper-Where-to-Reinforce-Where-to-Retreat.pdf

Seavitt, C. (2013). Yangtze River Delta Project, Scenario Journal 03: Rethinking Infrastructure.

Shanghai Municipal Government. (2012). Shanghai official rejects flooding claims. Retrieved from http://www.shanghai.gov.cn/shanghai/node27118/node27818/u22ai68648.html

Shih, S.-S., Yang, S.-C., \& Ouyang, H.-T. (2014). Anthropogenic effects and climate change threats on the flood diversion of Erchung Floodway in Tanshui River, northern Taiwan. Nat Hazards, 73, 1733-1747. http://dx.doi.org/10.1007/s11069-014-1166-8

Sinh, B. T., Bhat, G. K., Moench, M., \& Gawler, S. (2012). Building Resilience in Asian Cities. In Otto-Zimmermann (Ed.), Resilient Cities 2: Cities and Adaptation to Climate Change-Proceedings of the Global Forum 2011. Springer: Dordrecht, Heidelberg, New York, London. http://dx.doi.org/10.1007/978-94-007-4223-9_24

Su, Y.-S. (2015). Rebuild, Retreat, Or Resilience: Can Taipei Plan For Resilience? Ph.D. Dissertation in City and Regional Planning, University of Pennsylvania, U.S.A. Publicly Accessible Penn Dissertations. Paper 1149. Retrieved from http://repository.upenn.edu/edissertations/1149

Su, Y.-S. (2015). Urban Flood Resilience: A Chronology of Policies to Prevent Flooding in Taipei (November 21, 2015). http://dx.doi.org/10.2139/ssrn.2693969

Swiss Re. (2014). Natural Catastrophes and Man-made Disasters in 2013: Large Losses from Floods and Hail; Haiyan Hits the Philippines. No 1/2014. Zurich.

Taipei City Government. (2014). Taipei City Statistical Abstract 2013. Department of Budget, Accounting, and Statistics.

Taipei City Government. (2014). Taipei Yearbook 2013. Retrieved from http://yearbook.taipei/lp.asp?ctNode=73788\&CtUnit=40181\&BaseDSD=7\&mp=100103 (In Chinese)

Taipei City Government. Taipei City Statistics Website by Department of Budget, Accounting and Statistics. Retrieved from http://163.29.37.101/pxweb2007-tp/dialog/statfile9.asp (In Chinese)

Taiwan Central Weather Bureau (CWB)'s flooding maps. Retrieved from http://photino.cwb.gov.tw/tyweb/tyfnweb/image/ty-flood/1962amy-r.jpg (In Chinese)

Taiwan Central Weather Bureau (CWB)'s Typhoon DataBase. Retrieved from http://rdc28.cwb.gov.tw/ (In Chinese)

Taiwan Construction and Planning Agency. Retrieved from http://www.cpami.gov.tw/chinese/ (In Chinese)

Taiwan Ministry of the Interior. Retrieved from http://www.moi.gov.tw/stat/ (In Chinese)

Taiwan National Development Council. (2014). Urban and Regional Development Statistics. Retrieved from http://www.ndc.gov.tw/encontent/m1.aspx?sNo=0001452\#.VDW94SldXhp. (In Chinese) 
Taiwan Water Resources Agency. Retrieved from http://www.wra.gov.tw/ (In Chinese)

The City of New York. (2013). PlaNYC: A Stronger, More Resilient New York.

The Minister of Transport, Public Works and Water Management (MTPWM). (2005). Flood Risks and Safety in the Netherlands. Retrieved from http://ec.europa.eu/ourcoast/download.cfm?fileID=1058

The Minister of Transport, Public Works and Water Management (MTPWM). (2007). Room for the River Plan. Retrieved from http://www.ruimtevoorderivier.nl/english/room-for-the-river-programme/

The Minister of Transport, Public Works and Water Management (MTPWM). (2007). Safety for four million people in the Dutch delta Room for the River.

The Ministry of Transport, Public Works and Water Management (MTPWM). (2008). Flood risk: Understanding concepts. Ministry of Transport, Directorate-General of Water Affairs, Netherlands.

The NYS 2100 Commission. (2013). Recommendations to Improve the Strength and Resilience of the Empire State's Infrastructure

The World Bank. (2001). World Development Report 2000/2001: Attacking Poverty. New York: Oxford University Press.

The World Bank. (2005). Natural Disaster Hotspots: A Global Risk Analysis.

The World Bank. (2005). Natural Disaster Risk Management in the Philippines: Reducing Vulnerability.

The World Bank. (2009). Climate Resilient Cities A Primer on Reducing Vulnerabilities to Disasters: City Profiles Tokyo, Japan.

The World Bank. (2010). Economics of Adaptation to Climate Change: Bangladesh country study. World Bank, Washington D.C.

The World Bank. (2013). Building Urban Resilience: Principles, Tools, and Practice.

The World Bank. (2013). Turn Down Heat the Climate Extremes, Regional Impacts, and the Case for Resilience.

Thomas, V., Albert, J. R. G., \& Perez, R. T. (2013). Climate-Related Disasters in Asia and the Pacific. Asian Development Bank. http://dx.doi.org/10.2139/ssrn.2295783

Thompson, J. P. (2009). Response to "Post-Disaster Planning in New Orleans. Journal of Planning Education and Research, March, 28.

Tokyo Metropolitan Government. Retrieved from http://www.kensetsu.metro.tokyo.jp/c40/act6_E/PDF/Massive_flood_damage_of_Kano_River_Typhoon.pd $\mathrm{f}$

Trends in Japan. (2013). World-Class Underground Discharge Channel. Retrieved from http://web-japan.org/trends/11_tech-life/tec130312.html

UK's Environment Agency. (2001). Lessons learned Autumn 2000 floods.

UK's Environment Agency. (2012). Managing flood risk through London and the Thames estuary, Thames Estuary 2100 (TE2100) Plan.

United Nations Development Programme (UNDP). (2012). Putting Resilience at the Heart of Development.

United Nations International Strategy for Disaster Reduction (UNISDR). (2013). The Hyogo Framework for Action in Asia and the Pacific 2011-2013.

United Nations International Strategy for Disaster Reduction (UNISDR). (2005). Hyogo Framework for Action 2005-2015: Building the Resilience of Nations and Communities to Disasters.

United Nations International Strategy for Disaster Reduction (UNISDR). (2013). Making Cities Resilient: Summary for Policymakers. United Nations.

United Nations International Strategy for Disaster Reduction (UNISDR) and World Meteorological Organization (WMO). (2012). UN System Task Team on the Post-2015 UN Development Agenda: Disaster Risk and Resilience. United Nations.

United Nations International Strategy for Disaster Reduction (UNISDR). (2013). Using Science for Disaster Risk Reduction.

United Nations International Strategy for Disaster Reduction (UNISDR). (2012) Annual Report 2011. 
United Nations International Strategy for Disaster Reduction (UNISDR). (2015). World Conference Adopts New International Framework for Disaster Risk Reduction after Marathon Negotiations, Press release 18 March 2015.

United Nations. (2012). World Urbanization Prospects, the 2011 Revision: Highlights. United Nations Department of Economic and Social Affairs, Population Division. New York.

United Nations. (2012). World Urbanization Prospects: The 2011 Revision.

United Nations. (2013). The Global Assessment Report on Disaster Risk Reduction (GAR) 2013.

United Nations. (2014). Post-2015 framework for disaster risk reduction: Zero draft submitted by the co-Chairs of the Preparatory Committee. Third United Nations World Conference on Disaster Risk Reduction Preparatory Committee Second session, Geneva, 17-18 November 2014.

United Nations. (2014). Suggested elements for the post-2015 framework for disaster risk reduction. Third United Nations World Conference on Disaster Risk Reduction Preparatory Committee First session, Geneva, 14-15 July 2014.

United Nations. (2015). The Global Assessment Report on Disaster Risk Reduction (GAR) 2015.

Vale, L. J., \& Campanella, T. J. (2005). The Resilient City: How Modern Cities Recover from Disaster. Oxford University Press.

Wahlström, M. (2015). How can the world better prepare for natural disasters? World Economic Forum, Agenda. Retrieved from https://agenda.weforum.org/2015/03/how-can-the-world-better-prepare-for-natural-disasters/

Wang, C.-H. (2009). Imagine Taiwan in the year 2500. The Taipei Times, Dec. 16, 2009.

Wang, C.-H. (2013). Global Climate Change: Taipei Evacuation. Taiwan Environmental Information Center, May 28, 2013 (In Chinese).

Wang, L., Xie, Y., Wu, Y., Guo, Z., Cai, Y., Xu, Y., \& Zhu, X. (2012). Failure mechanism and conservation of the ancient seawall structure along Hangzhou bay, China. Journal of Coastal Research, 28(6), 1393-1403. $\mathrm{http}: / / \mathrm{dx}$.doi.org/10.2112/JCOASTRES-D-12-00036.1

Welsh, M. (2014). Resilience and responsibility: Governing uncertainty in a complex world. Geographical Journal, 180(1), 15-26. http://dx.doi.org/10.1111/geoj.12012

Wiering, M., \& Immink, I. (2006). When water management meets spatial planning: a policy-arrangements perspective. Environment and Planning C: Government and Policy, 24, 423-438. http://dx.doi.org/10.1068/c0417j

Woltjer, J., \& Al, N. (2007). Integrating Water Management and Spatial Planning. Journal of the American Planning Association, 73(2). http://dx.doi.org/10.1080/01944360708976154

Yin, J., Yu, D., Yin, Z., Wang, J., \& Xu, S. Y. (2013). Modelling the combined impacts of sea-level rise and land subsidence on storm tides induced flooding of the Huangpu River in Shanghai, China. Climatic Change, 119(3-4), 919-932. http://dx.doi.org/10.1007/s10584-013-0749-9

\section{Notes}

Note 1. Randstad is the Netherlands' most densely populated conurbation (urban agglomeration), including Amsterdam, Rotterdam, Utrecht, and the Hague. The population is more than 7 million, accounting for $44 \%$ of the national population.

Note 2. New York City's projection of flooding areas is based on each neighborhood, defined by the zip code. There are a total of 176 zip codes in New York City (41 zip codes in Manhattan, 37 in Brooklyn, 61 in Queens, 25 in the Bronx, and 12 on Staten Island)

Note 3. Greater London Authority (2012) estimates that over half a million people are at risk of flooding in London from tidal and fluvial sources. $70 \%$ of those at risk are at risk of tidal flooding, $29 \%$ are at risk of fluvial flooding, and $1 \%$ are at risk of flooding from both sources.

\section{Copyrights}

Copyright for this article is retained by the author(s), with first publication rights granted to the journal.

This is an open-access article distributed under the terms and conditions of the Creative Commons Attribution license (http://creativecommons.org/licenses/by/3.0/). 